\title{
Strategi Pengembangan Pondok Pesantren Al-Mu'awanah dalam Meningkatkan Kreativitas Santri
}

\begin{abstract}
ABSTRAK
Tujuan penelitian ini untuk mengetahui kemampuan pengelola pondok dalam meningkatkan kreatifitas santri, untuk mengetahui motivasi dan program di pondok pesantren Al-Mu'awanah dalam meningkatkan kreatifitas santri. Penelitian ini bermaksud untuk menjelaskan dan menggambarkan strategi pengembangan pondok Al-Mu'awanah dalam meningkatkan kreatifitas santri dengan menggunakan metode deskriptif. Tahapan dalam penelitian yakni memilih lokasi, metode penelitian yang digunakan, jenis data, sumber data, teknik pengumpulan data dan terakhir menganalisis data. Penelitian ini menunjukan bahwa pengelola pondok Al-Mu'awanah mampu meningkatkan kreatifitas santrinya sehingga sebagian besar santri dapat mengikuti berbagai program di pondok pesantren Al-Mu'awanah dengan baik dan lancar dan menciptakan berbagai kreatifitas santri sehingga santri mendapat penghargaan dari pondok dan kebanggaan bagi keluarganya. Motivasi yang diberikan dengan memberikan reward, hukuman terhadap santri yang melanggar, menyelenggarakan fasilitas pondok dan menyelenggarakan berbagai program kegiatan pondok sehingga mampu meningkatkan kreatifitas santri di pondok pesantren Al-Mu'awanah.
\end{abstract}

Kata kunci: Strategi Pengembangan; Pondok Pesantren; Kreativitas.

\begin{abstract}
The purpose of this study was to determine the ability of cottage management in increasing the creativity of santri, to find out the motivations and programs available at the boarding of Al$M u^{\prime}$ awanah Islamic boarding school in increasing the creativity of santri. The method used in this study is descriptive method, because the purpose of this study is to describe and provide an explanation of the development strategy in Al-Mu'awanah in increasing students' creativity. The steps taken in the research are determining the location of research, research methods, data types, data sources, data collection techniques, and finally analyzing. The results of this study indicate that the manager of $A l-M u^{\prime}$ awanah boarding school is able to increase the creativity of his santri. Motivation given by giving rewards, punishing the violating santri, provide facilities
\end{abstract}


and holding various activities programs to increase the creativity of santri boarded by AlMu'awanah Islamic boarding school.

Keywords: Development Strategy; Islamic Boarding School; Creativity.

\section{PENDAHULUAN}

Sebuah lembaga organisasi pada khususnya memerlukan strategi untuk mencapai target sesuai dengan yang diharapkan, sebuah organisasi tak lepas dari faktor manajemen dan strategi yang mana kedua hal itu saling berkaitan. Sehingga diperlukan strategi yang dijalankan dengan baik pula. Strategi merupakan rancangan kegiatan yang akan dilakukan untuk meraih tujuan dan sasaran yang telah dibuat, strategi dibutuhkan agar kegiatan dapat dilakukan dengan dengan lebih terarah.

Pengembangan (developing) adalah bagian dari kegiatan manajerial yang di dalamnya meliputi kegiatan pelatihan (coaching) sebagai salah satu kegiatan peningkatan mutu dan keterampilan seseorang untuk memudahkan proses penyesuaian diri di lingkungan pekerjaan agar dapat menunjang karirnya. Proses pengembangan dilakukan berdasarkan kesadaran, keinginan, keterampilan dan keahlian para komponen dakwah agar kegiatan dakwah dapat berjalan dengan efektif dan efisien.

Begitu juga dengan organisasi dakwah seperti yayasan atau pesantren yang turut mendukung peningkatan kreativitas santri. Salah satunya pondok pesantren salafiah yang berada di Cibiru wetan kecamatan Cileunyi kabupaten Bandung yang bernama pondok pesantren salafiah Al-Mu'awanah. Pondok pesantren ini letaknya tidak jauh dari kampus UIN Bandung. Pesantren ini tidak memiliki kawasan yang luas, pesantren ini adalah pesantren salafiah yang tempatnya sederhana namun dalam pembelajaran dan strategi pengembangan pesantren tersebut dapat dikatakan berhasil, sehingga dapat diakui oleh masyarakat sekitar dan dapat terlihat dari jumlah santri yang terus bertambah setiap tahun ajaran baru.

Hal ini juga terlihat melalui keaktifan dan keikutsertaan santri pada kegiatankegiatan pondok seperti pelatihan pidato, belajar ilmu nahwu shorof, qori dan memainkan berbagai alat kesenian islami baik itu marawis, qosidah, dan hadroh dari hari ke hari setelah program-program pondok pesantren dilaksanakan dapat terlihat berbagai kreativitas dari para santri. Hasil dari pelatihan kreativitas santri yang ada di pondok pesantren Al-Mu'awanah ini diantaranya, santri yang mengikuti kajian pelatihan pidato kini dapat berbicara di depan umum, padahal berbicara di depan umum itu bukanlah hal yang mudah bagi orang yang belum terbiasa kecuali dengan keterampilan dan keberanian yang sudah dilatih 
sebelumnya. Program yang diadakan di pondok pesantren salafiah AlMu'awanah dalam upaya meningkatkan kreativitas santri ini dinilai sangat membantu dan bermanfaat bagi para santri yang ingin mengembangkan bakat dan minat yang dimilikinya. Selain itu contoh dari strategi pengembangan kreativitas santri di pondok ini ialah dapat terciptanya santri-santri yang meraih prestasi di luar pondok baik itu dalam pidato, lomba kesenian dan lainnya. Tentunya ini merupakan sebuah kebanggaan pondok dan juga motivasi belajar untuk santri lainnya dan anak-anak di sekitar Cibiru wetan.

Strategi pengembangan di pondok pesantren merupakan hal yang penting terutama untuk mengembangkan eksistensinya dan meningkatkan kreativitas santri serta kemampuan organisasional untuk menghadapi masa depan yang semakin kompetitif. Setiap organisasi harus mampu mangantisipasi berbagai perubahan lingkungan yang terjadi, harus mampu merencanakan dan mewujudkan perubahan-perubahan secara internal dalam organisasi agar tantangan, masalah, ancaman, gangguan dapat dihadapi sehingga tercipta perubahan yang lebih baik.

Penelitian ini menggunakan metode penelitian deskriptif, yaitu suatu metode yang meneliti suatu objek, sekelompok manusia, suatu kondisi, atau sistem pemikiran atau pun suatu kelas pristiwa sekarang, yakni masalah-masalah yang sedang aktual. Berikut ini terdapat beberapa hasil penelitian sebelumnya yang memiliki kesamaan dengan penelitian ini, diantaranya:

Skripsi yang pertama disusun oleh Sofyan Anwar dengan judul skripsi Strategi Pengorganisasian Dakwah di Pondok Pesantren Simamiskin. Skripsi ini menjelaskan bahwa proses pengorganisasian di pondok pesantren Sirnamiskin ditempuh melalui; penentuan sasaran, penentuan kegiatan, pengelompokan kegiatan, bentuk organisasi dan diakhiri dengan pembuatan struktur organisasi.

Kesimpulan hasil akhir dari penelitian ini adalah Pondok Pesantren Sirnamiskin Bandung menggunakan sistem organisasi lini staf yang dimana Pemimpin Pondok merupakan pemilik kekuasaan tertinggi dan berkerja bersama para staf untuk mengoptimalkan kinerja dalam pelaksanaan dakwahnya. Pihak pesantren mengadakan kegiatan majlis ta'lim untuk santri dan masyarakat sekitarnya sebagai salah satu strategi dakwah.

Kesamaan skripsi penulis dengan yang disusun oleh Sofyan Anwar dengan judul skripsi Strategi Pengorganisasian Dakwah di Pondok Pesantren Sirnamiskin bahwasannya di dalam pesantren perlu adanya strategi baik itu dalam pengembangan pesantren, manajemen pesantren, dan pengorganisasian pesantren demi memajukan kualitas pesantren di masyarakat. Adapun yang menjadi perbedaannya bahwa pembahasan skripsi yang disusun oleh Sofyan 
Anwar dengan judul Strategi Pengorganisasian Dakwah di Pondok Pesantren Sirnamiskin, lebih membahas kepada proses pengorganisasian di pondok pesantren Sirnamiskin yang ditempuh melalui; penentuan sasaran, penentuan kegiatan, pengelompokan kegiatan, bentuk organisasi dan diakhiri dengan pembuatan struktur organisasi. Sedangkan skripsi penulis dengan judul Strategi Pengembangan Pondok Pesantren Al-Mu'awanah Dalam Meningkatkan Kreatifitas Santri, lebih membahas tentang bagaimana strategi yang diterapkan di pesantren Al-Mu'awanah dalam menumbuhkan kreatifitas santri yang ditempuh melaui program pembelajaran, strategi pengelola pesantren dan motivasi pesantren terhadap kreatifitas santri.

Ini bertujuan untuk menggambarkan, menerangkan dan mendeskripsikan data-data suatu informasi mengenai strategi pengembangan pondok pesantren Al-Mu'awanah dalam meningkatkan kreatifitas santri melalui observasi, wawancara dan studi kepustakaan secara menyeluruh terhadap objek penelitian. Kemudian dari data yang telah diperoleh dan terkumpul maka dilakukan analisis, dengan menggunakan metode deskriptif yang dapat membantu peneliti mendapatkan data yang akurat, benar dan lengkap berdasarkan data yang telah dikumpulkan dan dikelola secara sistematis.

Keberhasilan suatu organisasi atau lembaga-lembaga tertentu terletak pada manajemen organisasi atau lembaga itu sendiri. Maka dari itu pentingnya strategi dakwah dalam sebuah lembaga dakwah khususnya sebuah pesantren yang merupakan salah satu media pembelajaran. "Strategi merupakan rencana jangka pendek maupun jangka panjang tentang bagaimana perusahaan akan mencapai misinya. Strategi juga merupakan pedoman untuk menentukan keputusankeputusan dan hasilnya dimasa mendatang sesuai dengan arah kemana perusahaan akan bergerak." (Hasan,2011:27).

Jika dilakukan pengamatan yang teliti tentang sebab musabab keberhasilan atau kegagalan organisasi, akan terlihat bahwa ditinjau dari persepektif jangka panjang, hanya organisasi yang mampu untuk memuaskan kebutuhan masyarakatnyalah dengan efisien dan efektif yang dapat menjamin kelanggsungan hidupnya (Siagian,1933:13). Jadi pentingnya sebuah strategi di dalam organisasi terutama keorganisasian Islam seperti halnya pesantren.

Pengembangan (developing) adalah bagian dari kegiatan manajerial yang di dalamnya meliputi kegiatan pelatihan (coaching) sebagai salah satu kegiatan peningkatan mutu dan keterampilan seseorang untuk memudahkan proses penyesuaian diri di lingkungan pekerjaan agar dapat menunjang karirnya. Proses pengembangan dilakukan berdasarkan kesadaran, keinginan, keterampilan dan keahlian para komponen dakwah agar kegiatan dakwah dapat berjalan dengan efektif dan efisien. 
Menurut Hax dan Majluf (1991:100) yang dikutip dalam bukunya Djaslim Saladin yang berjudul Manajemen Strategi dan Kebijakan Perusabaan bahwa rumusan komprehensif tetang strategi yaitu: sebuah pola keputusan yang stabil dan jarang berubah-ubah, menyatu dan terintegral, mendeskripsikan tujuan dari organisasi jangka panjang, berusah meraih keuntungan dalam kurun waktu yang lama, mampu memberikan respon yang sesuai terhadap peluang yang ada dan ancaman dari luar organisasi dan kelebihan serta kekurangan dan menyangkut semua anggota di dalam organisasi. Menurut perumusan tersebut dapat didefinisikan, strategi merupakan suatu hal yang sangat mendasar dimana suatu organisasi akan mampu bertahan dalam waktu yang lama, sementara itu pada saat yang bersamaan mempunyai kekuatan untuk beradaptasi terhadap lingkungan yang tidak tetap.

Menurut McNicholis definisi yang lebih sederhana dari strategi yaitu sebuah seni dalam penggunaan keahlian dan sumber daya dari suatu organisasi yang bertujuan untuk meraih tujuannya yang efektif dalam lingkungan dan kondisi yang paling menguntungkan. Saladin menjelaskan bahwa Implementasi (pelaksanaan) suatu strategi adalah pelaksanaan strategi yang telah dirancang. Pelaksanaan strategi harus berjalan dengan konsisten maka harus dibangun sebuah susunan organisasi yang lengkap, sesuai, sesuai dengan anggaran, memiliki kejelasan sistem dan pengelola yang kompeten.

Saladin berpendapat suatu strategi akan sukses jika memiliki manager yang kompeten dan mampu mengelola personilnya dengan baik, tujuan dan strategi perusahaan harus bias dicerminkan melalui perusahaan, memiliki motivasi yang tinggi, memiliki rasa kesetiakawanan dalam lingkungan kerja, terdapat sistem yang menggabungkan strategi yang dimiliki dengan rencana pelaksanaan agar dapat diaplikasikan dengan sesuai dengan tujuan yang telah dirancang.

Kemampuan seseorang dalam menggerakan orang lain dalam mengikuti apa yang ia perintahkan tentunya hal ini sangat berpengaruh terhadap berjalannya strategi karena akan mempengaruhi setiap kegiatan dan setiap hal yang direncanakan dalam mewujudkan sebuah tujuan. Sehingga kemampuan manajer dalam menggerakan orang lain sangat diutamakan dalam berjalannya strategi. Selain itu strategi tidak lengkap jika tidak didukung oleh faktor sekitar seperti adanya motivasi yang tinggi dari perusahan dan juga terciptanya budaya yang menggambarkan rasa kesetiakawanan (positif) yang berkesinambungan sehingga akan membuat anggota dari perusahaan merasa nyaman dan diakui keberadaanya dan tentunya akan berpengaruh juga terhadap kinerjanya. Semakin anggota nyaman maka semakin baik pula kinerja yang dilakukan terhadap perusahaan. 


\section{LANDASAN TEORITIS}

Menurut Hasan strategi adalah rancangan perencanaan perusahaan jangka pendek maupun jangka panjang untuk mencapai misi dan tujuan. Strategi dibuat sebagai pedoman dalam pengambilan keputusan agar hasil akhir sesuai dengan apa yang diinginkan dan lebih terarah. Untuk mengembangkan sebuah organisasi atau lembaga apapun dibutuhkan sebuah strategi yang matang. Strategi berbeda dengan taktik, strategi bersifat umum, mendasar, bias, berjangka panjang atau berjangka pendek. Sedangkan taktik adalah reaksi dan rencana yang lebih dikhususkan lagi. Untuk mengembangkan sebuah organisasi atau lembaga apapun dibutuhkan sebuah strategi yang matang. Strategi berbeda dengan taktik, strategi bersifat umum, mendasar, bias, berjangka panjang atau berjangka pendek. Sedangkan taktik adalah reaksi dan rencana yang lebih dikhususkan lagi.

"Strategi dalam segala hal digunakan untuk mencapai tujuan yang ditetapkan. Tujuan tidak akan mudah dicapai tanpa adanya strategi, karena pada dasarnya segala tindakan atau perbuatan itu tidak terlepas dari strategi. Sedangkan taktik merupakan cara yang digunakan, dan merupakan bagian dari strategi. Strategi yang disusun, dikonsentrasikan, dikonsepsikan dengan baik dapat menjadikan pelaksanaan yang disebut stategis" (Rafi'udin, Djalil, 1997:77).

Jika dilakukan pengamatan yang teliti tentang sebab musabab keberhasilan atau kegagalan organisasi, akan terlihat bahwa ditinjau dari persepektif jangka panjang, hanya organisasi yang mampu untuk memuaskan kebutuhan masyarakatnyalah dengan efisien dan efektif yang dapat menjamin kelangsungan hidupnya (Siagian,1933:13).

Beberapa pengertian diatas dapat diartikan bahwa strategi merupakan sebuah perencanaan dalam bentuk jangka panjang dan jangka pendek yang dilakukan untuk mewujudkan sebuah tujuan dengan cara memanfaatkan sumber daya yang tersedia, sehingga apa yang menjadi tujuan dalam organisasi mampu terlaksana secara efekktif dan efisien.

Untuk mengembangkan sebuah organisasi atau lembaga apapun tentunya dibutuhkan sebuah strategi yang matang. Strategi berbeda dengan taktik, dalam hal ini strategi bersifat lebih umum, mendasar dan berjangka panjang atau pendek. Sedangkan taktik adalah tindakan, reaksi yang lebih khusus, operasional dan berjangka pendek yang digunakan untuk menyempurnakan sasaran terbatas. Kesimpulannya adalah taktik merupakan suatu pemaparan secara operasional dari strategi, sehingga strategi dapat diaplikasikan dengan baik dan dapat sesuai dengan tujuan. 
Menurut H. Dajslim Saladin dalam bukunya Manajemen Strategi dan Kebijakan Perusahaan (2003:30), strategi memiliki empat unsur strategi induk, diantaranya adalah sebagai berikut yaitu : Misi (mission) yakni mengidentifikasi rencana tujuan atau arah perusahaan, tujuan (objective) menurut William F. Glueck adalah "suatu pencapaian dari sebuah organisasi melalui kemampuan dan aktifitas yang dijalaninya, sasaran untuk strategi induk yang ketiga adalah membidik sasaran yang ingin dicapai dan petunjuk dari setiap bagian pengembangan kegiatan".

Strategi merupakan rencana secara menyeluruh dalam rangka mencapai misi, tujuan, dan sasaran. Adapun tahap-tahap strategi diantaranya: analisis lingkungan, perumusan strategi, implementasi strategi dan pengendalian strategi. Keempat strategi tersebut akan menjadi program bagi suatu perusahaan untuk mencapai target dan tujuan yang telah dibuat.

Segala tindakan harus diambil ketika tindakan ini diidentifikasi dan bermanfaat serta memiliki tujuan. Adapun manfaat dan tujuan dari strategi dapat diidentifikasi sebagai berikut (Bryson,2001:193), yaitu: gambaran yang cukup jelas akan muncul dari konsepsi besar hingga implementasi terperinci tentang bagaimana organisasi memenuhi mandatnya, mencapai misinya, dan secara efektif menanggulangi situasi yang dihadapinya. Gambar baru ini seharusnya muncul dari pertimbangan tentang sebarisan luas strategi alternatif, yang didalam dirinya seharusnya mempertinggi kretivitas organisasi dan mengatasi kecendrungan orgnisasi untuk melakukan pencarian solusi yang sederhana, singkat, dan sempit terhadap masalahnya. Jika tindakan diambil ketika tindakan itu diidentifikasi dan berguna untuk meraih realitas baru akan muncul dari kenyataan, bukan hanya dalam konsep. Implementasi awal atas sekurangkurangnya strategi pokok akan mendukung pengetahuan organisasi. Organisasi akan mampu menemukan dengan cepat apakah strateginya mungkin efektif, dan strategi itu bisa direvisi atau dikoreksi sebelum benar-benar diimplementasikan. Mempertinggi moral diantara para anggota tim perencanaan strategi, orangorang penting pembuat keputusan, dan anggota organisasi lainnya bisa berasal dari penyempurnaan tugas dan keberhasilan awal dalam pemecahan isu penting. Pengembangan tim perencanaan strategis selanjutnya (dan tentu saja pengembangan organisasi yang lebih luas) harus berasal dari disiplin yang terus menerus dalam memecahkan masalah pokok secara konstruktif. Anggota organisasi akan memiliki izin yang mereka butuhkan untuk terus maju dengan implementasi strategi. Jika semua manfaat dapat dicapai, organisasi akan mencapai kemajuan dalam cara yang efektif dan mulus.

Terdapat bermacam-macam jenis strategi, sesuai dengan kerangka tingkat dan waktu. Diantaranya ada empat tingkat yang mendasar dari strategi yang 
meliputi strategi besar untuk organisasi secara keseluruhan, strategi unit perencanaan perencanaan publik strategis (SPPU) atau unit perencanaan nirlaba strategis (SNPPU). Namun perlu dicatat jika organisasi secara keseluruhan dan SPPU maupun SNPPU sinonim, dua kategori pertama akan sama; jika tidak strategi SPPU atau SNPPU mungkin menjadi divisi, departemen, atau unit dari organisasi yang lebih besar, strategi program atau pelayanan, strategi fungsional (seperti keuangan, penempatan staf, fasilitas dan usaha pendapatan (Bryson,2001:190).

Menurut Qomar pesantren merupakan sebuah tempat menimba ilmu, tempat pendidikan dan pengajaran yang lebih menekankan kepada ilmu agama islam dan terdapat asrama sebagai sarana pendukung bagi para santri. Istilah pesantren kilat atau pesantren Ramadhan yang diadakan oleh sekolah tidak termasuk ke dalam pengertian ini. Pengertian lain tentang pesantren diungkapkan oleh Muljono Damopolii dalam bukunya "Pesantren Modern IMMIM (Ikatan Mesjid Mushola Indonesia Makasar” mengatakan bahwa:

"Pesantren secara terminologis yaitu sebagai lembaga pendidikan tradisional Islam untuk mempelajari, memahami, mendalami, menghayati danmengamalkan ajaran Islam dengan menekankan pentingnya moral keagamaan sebagai pedoman prilaku sehari-hari. Pengertian tradisional dalam definisi ini bukan berarti kolot, dan ketinggalan zaman, akan tetapi menunjuk pada pengertian bahwa lembaga ini telah hidup sejak ratusan tahun yang lalu. Ia telah menjadi bagian dari sistem kehidupan sebagian besar umat Islam Indonesia” (Damopolii,2011:58).

Haidar Putra Daulay juga mengungkapkan tentang pengertian pesantren dalam bukunya yang berjudul "Pendidikan Islam" bahwasannya pesantren sudah berdiri dan ada di Indonesia sejak ratusan tahun yang lalu. Kegiatan yang dilakukan lebih berfokus kepada pembelajaran ilmu dan nilai-nilai agama kepada para santri. Pada mulanya pesantren bertujuan hanya untuk mengajarkan ilmu agama, melalui kitab klasik atau kitab kuning. Berbagai cabang ilmu agama diajarkan di pesantren seperti, wetonan, sorogan, hafalan, atau pun musyawarah (muzakarah).

Qomar berpendapat bahwa ada pergeseran fungsi pesantren pada masa sekarang dibandingkan masa sebelumnya menjadi lebih berkembang, pada masa awal (Syaikh Maulana Malik Ibrahim) pesantren berpusat sebagai penyiaran agama islam. Di sisi lain pesantren berfungsi sebagai sebagai lembaga pembinaan moral dan kultural. A. Wahid Zaeni dalam buku Pesantren Dari Transformasi Menuju Demokratisasi Institusi beliau menjelaskan bahwa selain sebagai lembaga pendidikan, pesantren juga berfungsi sebagai lembaga yang bertugas untuk membina moral dan kultural para santrinya, baik antar santri maupun antar 
santri dan masyarakat. Dalam hal ini pendekatan kultural lebih banyak digunakan sebagai penyelenggara keadaan sosial di pesantren.

"Pertumbuhan pesantren sejak awal hingga sekarang telah melahirkan kategori tradisional dan modern. Istilah tradisional dan modern dipengaruhi waktu, sistem pendidikan, juga dipengaruhi ciri khasnya. Kategori pesantren tradisional yaitu pesantren yang masih dengan kebiasaan-kebiasaan terdahulu mulai dari metode pembelajaran maupun cara berpakaian. Selain itu, pondok pesantren tradisional, merupakan pesantren yang tetap mempertahankan pelajaran dengan kitab-kitab kelasik dan tanpa diberikan pengetahuan umum, model pengajarannya pun lazim diterapkan dalam pesantren salafi yaitu dengan metode sorogan atau wetonan" (Ghazali, 2003:14).

Pembelajaran ilmu agama islam dilaksanakan secara individual atau berkelompok dengan berfokus pada kitab-kitab klasik berbahasa arab. Pembagian jenjang dikelompokkan bersadarkan seberapa banyak kitab yang sudah dipelajari, bukan berdasarkan lamanya waktu. "Pesantren modern ialah pesantren non tradisional yang dalam pembelajarannya tidak mengikuti kebiasaan-kebiasaan dulu tapi mengikuti perubahan zaman. Pesantren modern juga merupakan pesantren yang menerapkan sistem pengajaran klasik (madrasah) memberikan ilmu umum dan ilmu agama, serta memberikan pendidikan keterampilan" (Ghazali, 2003:14).

Munculnya pesantren modern menimbulkan terjadinya perubahan metode, departemen RI memberi rincian bahwa metode penyampaian di pesantren masih ada yang bersifat tradisional (mengikuti kebiasaan lama), seperti bhalaghah, wetonan, dan sorogan. Adapula metode baru yang bersifat modern (metodeyang baru diperkenalkan ke dalam institusi berdasarkan pendekatan ilmiah). Meskipun sudah memasuki era modern, sejumlah pesantren masih menggunakan metode yang bersifat tradisional pada jaman sekarang. Menurut Arifin beberapa metode tersebut diantaranya metode wetonan, metode sorogan, metode mubawarah, metode mudzakarah, dan metode majlis ta'lim.

Pada dasarnya kegiatan di pondok pesantren bukan hanya berfokus pada kegiatan ilmu keagamaan, namun berkembang juga menjadi lembaga pengembangan masyarakat. Salah satu visi dan misi dari pondok pesantren adalah melahirkan kader-kader yang berkualitas di masa depan dengan perangkat di dalamnya yaitu masjid, pondok, kiai, santri dan pengajian.

Pengembangan (developing) merupakan suatu upaya untuk meningkatkan kompetensi teknis, konseptual, teknis dan moral para pegawai dengan kebutuhan pekerjaan atau jabatan melalui pelatihan dan pendidikan. Sehingga 
perlu adanya pengembangan pondok pesantren baik itu dari sumber daya manusia (SDM), manajemen pondok, perekonomian pondok dan lain sebagainya, yang bertujuan untuk meingkatkan berbagai keterampilan yang ada di pondok pesantren dan meningkatkan pengembangan pondok pesantren di lingkungan masyarakat.

Kini dunia industri dan perkembangan teknologi sudah menjadi andalan dunia modern, maka sebenarnya faktor peranan sumber daya manusia mejadi sangat penting dan tidak bisa lagi diabaikan. Karena itu, justru sumber daya manusialah yang akan menentukan apakah tujuan perkembangan teknologi dapat tercapai dengan tepat.

Sehingga para kiai dan banyak pihak mempunyai peran dan tanggung jawab agar out puts dari pesantren mempunyai bekal yang cukup dalam perkembangan teknologi di masa sekarang ini. Tentunya pengembangan yang dibutuhkan bukan hanya pengembangan SDM di masyarakat saja tapi juga pengembangan SDM di pondok pesantren. Pengembangan SDM pondok pesantren merupakan hal penting selain untuk mengembangkan kreativitas santri tapi juga untuk meningkatkan kualitas pesantren. Secara rinci disebutkan bahwa ada tujuh manfaat dari penyelanggaraan program pengembangan (Siagian.1999:183).

Pertama, peningkatan produktivitas kerja organisasi sebagai keseluruhan antara lain tidak terjadinya pemborosan, terjalinnya kerja sama diantara satuan kerja, lancarnya koordinasi, sehingga organisasi bergarak sebagai satu kesatuan yang utuh. Kedua, terjalinnya hubungan yang harmonis antara atasan dengan bawahan, karena terjadi pendelegasian tugas, interaksi yang didasarkan pada sikap dewasa secara teknikal maupun intelektual, saling menghargai dan adanya kesempatan untuk berfikir dan bertindak melakukan inovasi. Ketiga, proses pengambilan keputusan yang lebih cepat dan tepat dengan melibatkan seluruh komponen yang bertanggung jawab dalam penyelenggaraan program. Keempat, meningkatkan semangat kerja dan komitmen terhadap organisasi menjadi lebih baik. Kelima, mendorong sikap keterbukaan manajemen dengan gaya manajerial partisipatif. Keenam, terjalinnya komunikasi yang efektif yang mengakibatkan lancarnya proses perumusan kebijakan operasional dan organisasi. Ketujuh, penyelesaian konflik secara fungsional yang melahirkan tumbuh subur rasa persatuan dan suasana kekeluargaan di lingkungan organisasi.

Menurut Halim pada umumnya setiap orang paham bahwasanya kegiatan manajemen suatu lembaga atau organisasi termasuk pondok pesantren, pasti akan berkaitan dengan usaha meningkatkan kualitas dan kepemimpinan suatu tim kerja sama atau pada suatu kelompok dengan memanfaatkan sumber daya yang ada. Melihat keterkaitan itu, maka sudah wajar jika kemudian orang menyatakan bahwa manajemen sangat berhubungan erat dengan kepemimpinan 
dan kelembagaan termasuk lembaga pendidikan Islam misalnya pondok pesantren. Suatu pesantren tentunya harus memiliki manajemen yang baik untuk mengoptimalkan usaha-usaha pondok dalam mencapai suatu tujuan.

Manajemen sendiri jika dilihat dari etimologi berasal dari sebuah kata manage yang artinya memimpin, menangani, mengatur atau membimbing (Halim,Arif.2005:71). Pengertian manajemen di buku lain dikatakan bahwa manajemen berasal dari kata to manage yang artinya mengatur. Pengaturan dibuat berdasarkan proses dan diatur berdasarkan fungsi-fungsi manajemen itu sendiri. Sehingga bisa dikatakan manajemen merupakan proses dalam mewujudkan target dan tujuan yang ingin dicapai. Pentingnya manajemen terutama di pondok pesantren karena pada dasarnya pekerjaan sulit dilakukan oleh seorang diri, maka diperlukanlah pembagian kerja serta tanggung jawab dalam pelaksanaannya. Perusahaan akan berhasil dengan baik apabila memiliki system manajerial yang bagus, yang mampu meningkatkan kualitas dan potensi para karyawannya. Selain itu dengan adanya sistem manajerial yang baik maka akan mampu meminimalisir pemborosan-pemborosan, menetapkan tujuan dan usaha dalam rangka mewujudkan dan memanfaatkan 6M (men, money, methods, materials, machines, dan market). Manajemen merupakan suatu pedoman pikiran dan tindakan selalu dibutuhkan dalam setiap kerja sama kelompok.

"Manajemen jika dijabarkan menjadi sebuah proses tindakan meliputi beberapa hal diantaranya: perencanaan (planning) fungsi perencanaan mencakup penetapan tujuan, standar, penentuan aturan prosedur, dan pembuatan rencana serta prediksi apa yang diperkirakan terjadi. Pengorganisasian (organizing) fungsi pengorganisasian ini meliputi pemberian tugas yang terpisah kepada masing-masing pihak, membentuk bagian, mendelegasikan, atau menetapkan jalur wewenang atau tanggung jawab, dan sistem komunikasi, serta mengkordinir kerja setiap bawahan dalam suatu tim kerja yang solid dan terorganisir. Penggerakan (actuating), setelah kegiatan perencanaan dan pengorganisasian, pimpinan perlu menggerakan kelompok secara efisien dan efektif ke arah pencapaian tujuan. Dalam menggerakan kelompok ini pimpinan menggunakan berbagai sarana meliputi komunikasi, kepimpinan, perundingan-perudingan, pemberian intruksi, dan lain sebagainya. Melalui actuating ini, pimpinan berusaha menjadikan organisasi bergerak dan berjalan secara aktif dan dinamis. Pengawasan (controlling) fungsi ini bisa juga disebut dengan pengendalian atau evaluasi. Ketika organisasi telah bergerak dan berjalan, pimpinan harus selalu mengadakan pengawasan dan pengendalian juga evaluasi agar gerakan atau jalannya organisasi benar-benar sesuai dengan 
rencana yang telah ditetapkan, baik mengenai arahnya maupun caranya" (Halim,Arif.2005:72).

Pesantren secara sederhana dapat diartikan sebagai lembaga keagamaan yang berfokus mengajarkan, mendidik dan menyebarkan ilmu agama islam. Pengembangan pesantren tidak jauh berbeda dengan konsep pengembangan organisasi. Pengembangan organisasi dapat didefinisikan sebagai suatu "proses penyesuaian organisasi terhadap perubahan yang cepat melalui berbagai pendekatan teknostruktural" (Halim, Arif.2005:160). Pada dasarnya setiap organisasi akan berusaha untuk memaksimalkan hubungan antara atasan dengan bawahan terutama di sebuah lembaga organisasi.

"Dalam hal ini ada empat unsur yang mendorong atau mempengaruhi pengembangan lembaga atau organisasi yaitu: manusia dan perilaku, unsur ini penting karena aktivitas organisasi ditentukan oleh interaksi antarindividu atau antarkelompok, norma-norma informal, persepsi peran, kepemimpinan, konflik dalam kelompok dan sebagainya. Perilaku organisasi dalam banyak hal juga ditentukan oleh perilaku kelompok dan perilaku individu. Teknologi, yakni teknologi dapat diartikan sebagai tindakan yang dilakukan oleh orang terhadap objek, dengan atau tanpa alat bantuan perkakas, atau alat mekasis yang mengadakan perubahan tertentu dalam objek tersebut. Secara luas teknologi juga berarti penerapan pengetahuan untuk melaksanakan pekerjaan. Tugas, efisiensi organisasi dapat dicapai dengan menyusun tugas dan pekerjaan secara sistematis pembagian kerja fungsional atau spesialisasi menurut jenis pekerjaan. Struktur, yakni digunakan untuk mengendalikan organisasi dan membedakan bagian-bagiannya guna mencapai tujuan bersama. Yang dimaksud struktur adalah penentuan rentang kendali pelimpahan wewenang, yang membina aktivitas organisasi berjalan sesuai dengan apa yang telah direncanakan" (Halim,Arif.2005:160).

Komunikasi dalam pengembangan pondok pesantren merupakan hal penting karena tanpa komunikasi yang baik maka pesan-pesan pun tidak tersampaikan dengan baik pula sehingga proses dakwah pun tidak terlaksana dengan baik, begitu pun dengan pengembangan pesantren sangat diperlukan komunikasi yang baik dalam pengembangan pesantren, baik itu komunikasi antar santri maupun komunikasi santri dengan kiai.

Komunikasi merupakan dasar dari setiap usaha antar manusia. Pada komuniksi info atau ide (buah pemikiran) disampaikan oleh pihak pertama. Tujuannya ialah menyampaikan informasi sehingga ada kesesuaian paham (Gondokusumo.1983:1). Adapun pengertian lain bahwasannya komunkasi 
merupakan proses penyampaian pesan dari komunikator kepada komunikan dengan tujuan makna yang sama (Halim,Arif.2005:131).

"Komunikasi dapat dikatakan berhasil jika adanya timbal balik mengenai pesan dari komunikator yang diterima oleh komunikan, dan perlu diketahui ada beberapa faktor yang dapat mempengaruhi komunikasi informasi diantaranya: kemampuan pihak pertama untuk memahami informasi yang akan dikomunikasikan dan memahami pula akibat-akibatnya, kemampuan pihak pertama (komunikator) untuk menyusun informasi itu dalam bahasa yang dapat ditangkap dan dimengerti oleh pihak kedua (komunikan), dan menyusunnya dalam bentuk yang dapat menimbulkan hanya satu paham, kemampuan dan kemauan pihak kedua untuk menangap dan memahami informasi yang disampaikan, kemampuan dan kemauan pihak kedua untuk mengemukakan pahamnya mengenai apa yang ditangkapnya (dipersepsinya), terutama ada perbedaan antara pahamnya dan informasi yang diterimanya, kemauan pihak kedua untuk menyesuaikan pahamnya dengan informasi itu, kemauan pihak pertama untuk mengetahui belum tercapainya kesesuaian paham dan kemauannya untuk mengusahakan kesesuaian itu" (Gondokusumo.1983:5).

Pentingnya komunikasi di pondok pesantren melainkan keseharian santri yang tidak lepas dengan sosialisasi baik itu dengan sesama santri maupun dengan pengurus-pengurus pesantren bahkan dengan kiainya. Sehingga perlunya komunikasi yang baik di pondok pesantren, agar tidak ada kesalahpahaman tugas kerja maupun dengan pembelajaran di pesantren. Selain itu pentingnya komunikasi di pesantren juga untuk menjalin hubungan baik antar santri dengan santri, santri dengan pengurus pondok maupun dengan kiai di pondok.

\section{HASIL DAN PEMBAHASAN}

Pondok pesantren salafiah Al-Mu'awanah berada di Cibiru Hilir Kp.Lio Warunggede RT 04 RW 12 Desa Cibiru Kecamatan Cileunyi Kabupaten Bandung Provinsi Jawa Barat. Letak pondok pesantren Al-Mu'awanah tidak jauh dengan Universitas Islam Negri Bandung sehingga santrinya pun kebanyakan merupakan mahasiswa UIN Bandung. Selain itu di pondok pesantren AlMu'awanah juga terdapat TK, RA dan madrasah diniah.

Untuk mengembangkan sebuah organisasi atau lembaga apapun dibutuhkan sebuah strategi yang matang. Strategi berbeda dengan taktik, strategi bersifat umum, mendasar, bias, berjangka panjang atau berjangka pendek. Sedangkan taktik adalah reaksi dan rencana yang lebih dikhususkan lagi. Sebuah lembaga organisasi pada khususnya diperlukan strategi agar apa yang menjadi tujuan 
dapat tercapai sesuai harapan, berikut strategi pengembangan yang ada di pondok pesantren Al-Mu'awanah:

Strategi merupakan rencana jangka pendek maupun jangka panjang tentang bagaimana perusahaan akan mencapai misinya. Strategi juga merupakan pedoman untuk menentukan keputusan-keputusan dan hasilnya di masa mendatang sesuai dengan arah kemana perusahaan akan bergerak (Hasan,2011:27).

Dari hasil wawancara dengan pengelola pondok pesantren Al-Mu'awanah bahwa dalam menumbuhkan kreatifitas santri perlu adanya strategi yang diterapkan diantaranya:

Pertama, dengan mengajarkan santri pelajaran ilmu agama dari dasar, ada empat waktu pengajian setiap harinya dan setiap pengkajian itu berbeda-beda, karena di pondok pesantren Al-Mu'awanah ada waktu-waktu ketika pelajaran yang sudah dipelajari diulang kembali kepada pembahasan awal yang bertujuan untuk mempermudah santri baru dalam memahaminya dan juga mengingatkan santri lama dengan pembahasan-pembahasan yang telah dipelajari sebelumnya. Pondok pesantren Al-Mu'awanah memilikitiga tingkatan kelas yaitu kelas ula sebagai kelas pemula, kelas wusto sebagai kelas pertengahan, kelas ulya sebagai kelas tertinggi yang merupakan tingkatan ketiga.

Dari hal tersebut dapat disimpulkan bahwa dengan mengajarkan santri ilmu-ilmu agama dari dasar, hasilnya santri mendapatkan banyak manfaat seperti merasa nyaman saat mengikuti pembelajaran di pesantren, bertambahnya rasa percaya diri terutama bagi santri yang baru mengenal pesantren dan lainnya.

Kedua, dengan menumbuhkan kesadaran santri sebagai seorang santri. Pengelola pondok Al-Mu'awanah merupakan ciri pemimpin yang kharismatik, sehingga kehadiran beliau di pondok pesantren salafiah Al-Mu'awanah sangat disegani dan dihargai.

Pengelola pondok pesantren Al-Mu'awanah selalu menasehaati santri bahwa dalam menumbuhkan kesadaran santri bahwa ia adalah seorang santri artinya seorang santri harus menyadari bahwa ketika ada di pondok pesantren bukan hanya pindah tidur, pindah makan dan pindah tinggal saja akan tetapi seorang santri memiliki tanggung jawab dan kewajiban yang harus ia kerjakan sebagai seorang santri. Kewajiban yang harus dikerjakan seperti mengaji, mematuhi aturan pondok, dan tentunya memperbaiki akhlak. Seorang santri yang benar-benar menyadari bahwa semua itu adalah kewajibannya dan bukan hanya tuntutan semata dari pondok, maka santri akan menjalankannya dengan tulus tanpa harus diperintah sehingga apa yang ia kerjakan akan menjadi sebuah kebiasaan dalam kesehariannya, begitu pun dalam meningkatkan kreativitasnya 
jika sudah terbiasa maka akan menjadi suatu keseharian dalam meningkatkan kreativitas. Dapat disimpulkan bahwa menumbuhkan kesadaran santri sebagai seorang santri, dalam pelaksanaan strategi ini santri dilatih untuk terbiasa dengan kegiatan-kegiatan santri sehingga santri pun terbisa ketika meningkatkan kreativitas

Ketiga, adanya tindak lanjut langsung terhadap yang melanggar, artinya ketika ada santri yang tidak mematuhi aturan pondok pesantren maka pengelola pondok langsung menindak lanjut santri yang bersangkutan tersebut. Adapun tindak lanjut bagi santri yang melanggar itu bisa oleh Rohis dan juga Ustad Iwan Hermawan, tapi kebanyakan ditangani langsung oleh Ustad Iwan selaku pengelola pondok pesantren Al-Mu'awanah termasuk ada beberapa pelanggaran pondok yang tidak bisa ditangani oleh kepengurusan Rohis melainkan langsung ditanganinya oleh Ustad Iwan Hermawan selaku pengelola pondok dengan memberinya perhatian berupa sanksi. Sanksi yang diberikan biasanya berbentuk tugas-tugas pengajian bukan berbentuk materi. Adapun pelanggaran-pelanggaran yang langsung ditangani Ustad Iwan Hermawan diantaranya seperti keterlambatan santri yang pulang ke pondok, santri yang tidak ikut pengajian tanpa alasan yang jelas dan lainnya.

Bahwa dapat disimpulkan dari strategi yang dilakukan pengelola pondok dapat meningkatkan kreatifitas santri dan kedisiplinan santri dalam mengikuti kegiatan di pondok pesantren serta menjadikan pondok pesantren yang diterima oleh warga setempat, hal ini terbukti dengan banyaknya warga yang menitipkan anaknya untuk menimba ilmu di pondok pesantren Al-Mu'awanah.

"Motivasi adalah pemberian daya penggerak yang menciptakan kegairahan kerja seseorang, agar mereka mau bekerjasama, bekerja efektif dan terintegrasi dengan segala daya upayanya untuk mencapai kepuasan” (Hasibuan,2006:219).

Pondokpesantren Al-Mu'awanah dalam memotivasi santri untuk meningkatkan kreatifitasnya yaitu dengan :

\section{Pondok Pesantren Memberikan Reward}

Melalui berbagai perlombaan di pondok pesantren Al-Mu'awanah ini dapat memotivasi santrinya dalam meningkatkan kreativitas diantaranya pandai dalam berpidato hingga menjadi juara dalam perlombaan, pandai memainkan berbagai alat musik islami, melatih hafalan santri baik itu hafalan hadist, al-qur'an, dan nadhoman, dan pandai melatih keterampilan dengan mengikuti kegiatan alginayah yang mana dalam kegiatan tersebut santri dilatih untuk dapat membuat kreatifitas dari benda-benda. 


\section{Memberikan Hukuman Terhadap Santri Yang Melanggar}

Memberi hukuman kepada yang melanggar dengan tujuan memotivasi santri lainnya agar mau menuntut ilmu lebih baik lagi. Kreatifitas tidak hanya dengan pandai pidato, sholawatan, kaligrafi saja akan tetapi dengan menuntut ilmu di pondok dengan serius tentunya akan melahirkan santri yang pandai dalam ilmu agama baik itu dalam pemahaman ilmu agama maupun dalam hafalan seperti hafalan Al-Qur'an dan hafalan (hasil wawancara dengan Ust.Iwan Hermawan).

\section{Menyelenggarakan Fasilitas Pondok}

Pemberian motivasi dari pondok pesantren itu sendiri terkadang ada yang berupa fasilitas-fasilitas pondok meskipun pada saat sekarang memang masih terlihat minim akan tetapi masih dalam proses pengembangan, artinya selalu ada perkembangan dari tahun ketahun mengenai fasilitas di pondok pesantren $\mathrm{Al}$ Mu'awanah.

Dari berbagai hal yang dilakukan untuk memotivasi santri dalam meningkatkan kreativitasnya dapat disimpulkan bahwa pemberian motivasi perlu adanya untuk mendukung strategi yang diterapkan agar bisa terlaksana dengan baik. Motivasi yang diberikan tidak harus berupa reward tapi adakalanya berupa hukuman untuk membangun semangat santri dalam menuntut ilmu dan meningkatkan kreatifitas, hal ini terbukti di pondok pesantren Al-Mu'awanah yang memberi motivasi santri salah satunya dengan memberi hukuman terhadap yang melanggar sehingga membuat santri lainnya menjadi lebih tekun dan lebih rajn serta tertib dalam mengikuti kegiatan yang ada di pondok pesantren $\mathrm{Al}$ Mu'awanah.

Adapun program pondok pesantren Al-Mu'awanah dalam meningkatkan kreatifitas santri diantaranya: Kegiatan harian, kegiatan mingguan, kegiatan bulanan dan kegiatan tahunan.

Jadi dalam strategi pengembangan pondok pesantren Al-Mu'awanah dalam meningkatkan kreativitas santri dapat saya simpulkan bahwa strategi yang dilakukan di pondok pesantren Al-Mu'awanah memang tidak jauh beda dengan pesantren-pesantren lain pada umumnya hanya saja yang menjadi pembeda, selain pengelola pesantren yang memiliki kharisma tapi juga pembelajaran yang mengadakan waktu pembelajaran dari awal serta pondok pesantren menerapkan berbagai kegiatan serta motivasi yang dapat menumbuhkan kreatifitas santri, dengan adanya berbagai perlombaan khususnya disetiap hari-hari besar Islam sehingga lebih memudahkan santri dalam meningkatkan kreativitasnya dari tahun ke tahun. 


\section{PENUTUP}

Berdasarkan hasil penelitian tentang strategi pengembangan pondok pesantren Al-Mu'awanah dalam meningkatkan kreatifitas santri, maka dalam pelaksanaannya menghasilkan santri yang aktif dan memiliki kreatifitas yang baik sehingga mendapatkan berbagai reward dari pesantren dan ini pun selain menjadi kebanggaan bagi keluarganya tapi juga memotivasi santri lainnya dalam meningkatkan kreatifitas dan juga memberikan kemudahan bagi santri untuk memiliki pilihan sesuai bakatnya.

Selain itu santri yang mengikuti kegiatan al-ghinayah dapat mendapatkan berbagai pengetahuan baru khususnya dalam mengolah barang-barang sederhana bahkan barang bekas menjadi lebih bermanfaat dan dijadikan suatu penghasilan pula.

Pondok pesantren Al-Mu'awanah dalam meningkatkan kreatifitas santri juga disertai berbagai strategi diantaranya:

1. Mengajarkan santri ilmu-ilmu agama dari dasar, hasilnya santri mendapatkan banyak manfaat seperti merasa nyaman saat mengikuti pembelajaran di pesantren, bertambahnya rasa percaya diri terutama bagi santri yang baru mengenal pesantren dan lainnya.

2. Menumbuhkan kesadaran santri sebagai seorang santri, dalam pelaksanaan strategi ini santri dilatih untuk terbiasa dengan kegiatan-kegiatan santri sehingga santri pun terbisa ketika meningkatkan kreativitas.

3. Adanya tindak lanjut langsung terhadap yang melanggar, hasil dari pelaksanaan strategi ini santri selain menjadi lebih disiplin tapi juga karena bentuk sanksinya berupa tugas-tugas pengajian maka santri mengakui bahwasannya dengan adanya sanksi seperti ini dapat meniningkatkan semangat santri dalam menimba ilmu maupun dalam meningkatkan kreatifitas dan menjadikan santri lebih aktif lagi dalam mengikuti kegiatankegiatan di pesantren. Strategi yang dilakukan pengelola pondok dapat meningkatkan kreatifitas santri dan kedisiplinan santri dalam mengikuti kegiatan di pondok pesantren serta menjadikan pondok pesantren yang diterima oleh warga setempat, hal ini terbukti dengan banyaknya warga yang menitipkan anaknya untuk menimba ilmu di pondok pesantren AlMu'awanah.

Strategi yang dilakukan di pondok pesantren Al-Mu'awanah memang tidak jauh beda dengan pesantren-pesantren lain pada umumnya hanya saja yang menjadi pembeda, selain pengelola pesantren yang memiliki kharisma tapi juga pembelajaran yang mengadakan waktu pembelajaran dari awal serta adanya 
Nurholisoh, A., Fachruroji dan Solahudin

berbagai perlombaan disetiap hari-hari besar Islam sehingga lebih memudahkan santri dalam meningkatkan kreatifitasnya. 


\section{DAFTAR PUSTAKA}

Daulay, Haidar, Putra. 2004, Pendidikan Islam, Jakarta: Kencana

Damopolii, Muljono. 2011, Pesantren Modern IMMIM (Ikatan Mesjid Mushola Indonesia Makasar, Jakarta: Rajawali Pers

Galba, Sindu. 1991, Pesantren Sebaagai Wadab Komunikasi,Jakarta:PT Rineka Cipta Gondokusumo. 1983, Komunikasi Penugasan, Jakarta: PT.Gunung Agung

Halim, Suhartini, Arif Choirul, Sunarto. 2005, Manajemen Pesantren, Yogyakarta: Pustaka Pesantren

Hasan, irmayanti. 2011, Manajemen Operasional Persepektif Integratif, Malang: UINMALIKI PRESS

Hasibuan, Malayu SP. 2006, Manajemen Dasar, Pengertian dan Masalah, Jakarta: Bumi Aksara.

M.Bryson, John.2001, Perencanaan Strategis Bagi Organisasi-Organisasi Sosial, Yogyakarta: Pustaka Pelajar

Masyhud, Sulthon dan Khusnurdilo. 2005, Manajemen Pondok Pesantren, Jakarta: Diva Pustaka

Munir, Muhammad dan Ilahi, Wahyu. 2006, Manajemen Dakwah. Jakarta: Prenada Media

Qomar, Mujamil. 2002, Pesantren Dari Transformasi Menuju Demokratisasi Institusi, Jakarta: Erlangga

Rafi'udin, dkk. 2000. Prinsip dan Strategi . Bandung: Pustaka Setia.

Saladin, H.Djaslim. 1999, Manajemen Strategi Dan Kebijakan Perusahaan. Bandung: Linda Karya

Siagian, Sondang.P. 1999, Manajemen Sumber Daya Manusia. Jakarta: Bumi Aksara

Sri Wahyudi, Agustinus. 1996, Manajemen Strategik, Medio: Binarupa Aksara 